\title{
Свободный жанр
}

\author{
ІІІести деся тники
}

\section{Василий Аксенов о Владимире Высоцком}

DOI: $10.31425 / 0042-8795-2018-4-191-198$

\section{Виктор Михайлович Есипов}

литературовед

Институт мировой литературы им. А. М. Горького РАН

(121069, Россия, г. Москва, ул. Поварская, д. 25а;

email: wogeman@mail.ru)

\section{Андрей Павлович Кулик}

литературовед

(620036, Россия, г. Екатеринбург, ул. Соболева, д. 21/3;

email: nihil1@yandex.ru)

Аннотация. Публикуется выступление В. Аксенова на радио «Свобода» в июле 1983 года, посвященное личности В. Высоцкого. В. Аксенов признался, что ко многому успел привыкнуть в эмиграции, но так и не смог смириться с мыслью, что «Володи нет среди живых». В. Аксенов подробно вспоминает свои встречи с В. Высоцким и эпизоды его жизни, в частности историю издания альманаха «Метрополь».

Ключевые слова: В. Аксенов, В. Высоцкий, «Метрополь».

Статья поступила 01.12.2017. 
Прошло три года с того парижского вечера, когда я подошел к телефону-автомату с намерением впервые позвонить в Москву простым набором цифр. Перекресток СенЖермен-де-Пре был до предела забит машинами и толпой гуляк. Модные в том сезоне светящиеся шнурки были обмотаны у людей вокруг шей, запястий, щиколоток, торчали из волос, извивались в пальцах. Странные, светящиеся в сумерках разноцветные шнурки, возбужденные лица, факелы в руках жонглеров и пожирателей огня, саксофоны, скрипки и гитары в руках уличных музыкантов - как это все отличалось от вымершей в предолимпийском ступоре Москвы, которую я покинул всего три дня назад, отправляясь, так сказать, в заграничный вояж, а фактически - в бессрочную ссылку.

Набросав в машину сколько полагается франков, я набрал телефон московского друга ${ }^{1}$ и сказал ему с фальшивой бодростью: «Вообрази - звоню тебе прямо с бульвара Сен-Жермен!» В ответ я услышал нечто невероятное: «У нас вчера ночью случилось страшное несчастье - умер Володя Высоцкий».

За эти три года произошло немало перемен, к которым мы уже успели привыкнуть. Кончился, например, брежневский зрелый социализм, и начался андроповский, не совсем зрелый. Отрезана была прямая телефонная связь с Советским Союзом, и зарубежные русские, пошумев и повозмущавшись, уже привыкли, что Москва снова отсоединилась от современного человечества и более туда с бульвара Сен-Жермен не позвонишь. Невозможно только привыкнуть, что Володи нет среди живых.

Мы с ним никогда не были закадычными корешами. Таких, как я, друзей у него было десятки. Кажется, и познакомились-то мы с ним только во второй половине 60-х, в свите Марины Влади. Звезда французского кино тогда стала довольно часто приезжать на родину своих родителей, русского пилота Полякова и мамы-смолянки (имеется в виду Смольный институт благородных девиц, впоследствии давший приют небезызвестной группе мужчин).

Марина разгуливала по Москве в голубом костюме с красной шалью на плечах, что в сочетании с соломенной 
гривой создавало трехцветие какой-то неопознанной свободы. Писатели, актеры и киношники нашей «волны» как раз волной ей и сопутствовали. Московские мамани злились: «Ишь, девка вырядилась, как Марина Влади!»

Наши все время тогда как-то кучковались, кутили и воспаряли, некто хриплый из свиты пел нечто бунтарское, про охоту на волков. Потом она за него и замуж вышла.

В последующие годы встречались, конечно, чаще, но еще чаще разъезжались. Приедешь куда-нибудь в Одессу или Ялту, увидишь дружественную трубу теплохода «Грузия» ${ }^{2}$, устремишься, и тут капитан ${ }^{3}$ тебе и говорит: «А с нами Марина и Володя целую неделю плавали, вчера сошли в Сухуми». Прискачешь как-нибудь посреди зимы в Приэльбрусье, а там тебе говорят: «А мы только вчера Высоцкого проводили, здорово он у нас тут выступил!»

Одна из моих любимых Володиных песен, кстати, связана с горами, где «голубым сияньем льдов весь склон облит». Как он там поет?

В тот день шептала мне вода:

«Удач всегда!»

А день, какой был день тогда?

Ах, да, среда...

Где-то в середине 70-х годов мы стали с Высоцким встречаться чаще. Я дал ему прочесть только что написанный «Ожог». Собственно говоря, он был одним из немногих реальных героев этой книги. Под собственным именем он там гонял по ночной Москве на своей иномарке и в подвале пел для джазистов:

$$
\begin{aligned}
& \text { Удар, удар, еще удар, } \\
& \text { Опять удар, и вот } \\
& \text { Иван }{ }^{4} \text { Буткеев (Краснодар) } \\
& \text { Проводит апперкот... }
\end{aligned}
$$

Володя на роман тогда, что называется, завелся - оставил у себя один экземпляр опасной рукописи и сказал, что собирается начитать весь текст на пленку. Насколько я знаю, он это и делал время от времени, но на весь текст у него времени не хватило... 
Читал он мне тогда и отрывки из своей собственной прозы, из романа «Девочки». Не знаю, насколько он продвинулся в этом деле, - времени у него всегда не хватало, да и задница у него к писанию прозы не была приучена. В тех отрывках, что я слышал, описывались московские красотки, подцепляющие «фирмУ», то есть иностранцев.

Он был с начала и до конца подлинным, на двести процентов, москвичом, хитроватым, лукавым уличным парнем, эдаким идеалом задавленной мужской вольницы. В кожаной курточке до пояса и кепке набок (его любимая одежда) он походил на эдакий тертый калач, на столичного таксиста, да, в общем-то, и вся его жизнь порой смахивала на таксистский городской миф.

В 70-е глухие годы он на своем могучем «Мерседесе300» каждый год по нескольку раз пересекал то, что на замке, то есть государственную границу СССР. С одной стороны, этому, конечно, способствовало наличие жены в Париже, но с другой стороны - и не в малой степени то, что среди миллионов обожателей его песен были не только интеллектуалы, диссиденты, студенты, работяги, бродяги, но и милиция, но и пограничники, и даже чиновники ОВИРа. Даже они считали его своим и спускали ему многое, что другим бы не простилось.

Как-то он вернулся из долгого путешествия и пошел в ОВИР сдавать заграничный паспорт. Начальник канцелярии, какой-то генерал, пригласил его в кабинет, нахмурил большущие (тогда они были среди начальства в моде) брови: «Как вы оказались в США, товарищ Высоцкий? Ведь мы вам визу выдавали-то только для поездки во Францию!» - «В США-то? Вы сказали - в США? - хитро сощурился актер. - Ах, да, в США... Ведь мы, в самом деле, в США оказались... Ну так это просто проездом, товарищ генерал». - «Проездом куда?» - вспучился генерал. - «Да на Таити же, то есть на тихоокеанскую территорию Франции!» - «А на Таити что вас занесло?!» У стража границы священной от таких слов, как «Таити», слегка кружилась голова. «А у нас там дети, товарищ генерал!» - обезоруживающе улыбнулся Володя и не соврал. На Таити действительно находились тогда Маринины сыновья, Игорь и Владимир. 
Когда возникла идея альманаха «Метрополь», среди возможных авторов было названо имя Высоцкого. «"Метрополь” - это журнал нашей метрополии, то есть Москвы и русской земли, - рассуждали зачинщики. - Надо, чтобы и певец этой земли был среди нас, тем более что его тексты никто никогда не печатал».

Я поехал к нему тогда на Малую Грузинскую в знаменитый кооператив, в подвале которого иногда устраивались выставки нонконформистов под строгим наблюдением конформистов. Володя пришел в восторг от приглашения в «Метрополь» и сразу вытащил толстую папку своих текстов: «Отбирайте». Он только что вернулся из-за границы и был в тот вечер в очень приподнятом настроении, хотя и не пил ничего, кроме крепчайшего чаю. Его прямо распирали тогда всякие художественные идеи: «Вот если окажемся как-нибудь вместе с тобой ТАМ (то есть на Западе), давай поставим сногсшибательный фильм, а? Ты напишешь сценарий, а я срежиссирую и сыграю, а? Или вот есть идея международного русского культурного центра, мы с Шемякой ${ }^{5}$ недавно обсуждали...»

Как у многих людей его склада, его творческое и физическое состояние напоминало гонку по американским горам: ups \& downs, взлеты и падения. Иногда после слишком высокого парения он попадал в настоящие ямы, из которых не без труда выбирался. Еще в конце 60-х годов Вознесенский, помнится, написал стихи о смерти и реанимации Высоцкого 6 .

В новогоднюю ночь 1980 года нам случилось быть в подмосковном поселке Пахра. Мы сидели в узком кругу друзей, а Высоцкий с Мариной пировали на соседней роскошной даче одного кинодраматурга. Там же был Юрий Трифонов. Часа в два ночи созвонились, и мы отправились к ним, воссоединяться. Ну, думаем, гульба там идет - небу, наверное, жарко. И вдруг видим: человек, наверное, тридцать гостей молодого и среднего возраста чинно сидят в креслах и в полном молчании смотрят по телевизору новогодний концерт. «Вот это называется кризисом жанра, - сказал Высоцкий, - настоящий кризис жанра. Давайте, ребята, договоримся: я завтра к Юре (Трифонову) приду с гитарой и для вас попою». 
Он не пришел петь, а вместо этого подхватился и на бешеной скорости помчался по ледяному шоссе в Москву, вдребезги разбил свой «Мерседес» - кажется, уже второй по счету. Что его понесло тогда в Москву? Близкие говорили, что он просто не мог долго сидеть на одном месте.

В разгар антиметропольской кампании, когда начались уже исключения из Союза писателей и всем стало ясно, какая тяжеленная махина на нас давит, Володя (к «Метрополю» он имел, в общем-то, непрямое отношение, карательные акции его не коснулись, должно быть, власти считали, что злокозненные писатели просто затащили невинного певца обманом в свою компанию) вдруг позвонил мне. Произошел странноватый разговор. «Ты знаешь, - сказал он весело, - я недавно, будучи в Бухаре, умер. Ну что там объяснять? Рыбой отравился. Хорошо, что со мной друг был, Валера, доктор по профессии. Он мне укол сделал прямо в сердце, и вот я ожил» ${ }^{7}$. Потом добавил еще веселее: «Косая прямо ходит по пятам!» И, после некоторого молчания: «Слушай, я хочу тебе дать тысячу рублей. Почему? Да просто так. Ну просто есть у меня лишняя тысяча, вот и хочу тебе ее дать. Ну просто чтобы ты не менял свой образ жизни из-за всей этой лажи».

Честно говоря, я был очень растроган, но тысячу не взял. Как ни странно, в деньгах я тогда недостатка не испытывал: почти во всех союзных республиках - видимо, в противовес Москве - издали мои книжки и прислали гонорары. «Спасибо, Володя, денег не надо. А вот ты лучше приходи к нам, на собрание "Метрополя". Публика очень будет рада тебя видеть». - «Приду-приду!» - пообещал он. Потом я пожалел, что пригласил его: зачем втягивать человека в неприятности? Ведь за нами тогда очень плотно следили. Впрочем, подумал я, артисты народ легкомысленный, пообещает и забудет.

Штаб-квартира альманаха помещалась в однокомнатной квартирке моей покойной матери, Евгении Гинзбург. Когда там собирались все авторы, да еще и их подруги, возникала атмосфера вагона метро в час пик.

В тот вечер настроение у всех было неважное. Бонзы Союза писателей по приказу, конечно, соответствующих 
органов закручивали гайки все туже, да еще и гнусные сплетни распускали. Вдруг вошел Высоцкий с гитарой и устроил нам маленький концерт.

Мы все вдруг ожили, ощутив себя как бы в лучах звезды, да он и был ведь суперзвездой, и от него в лучшие его творческие часы шел мощный заряд животворной праны. Он пел тогда и «Волков», и «Баньку», и «Купола в России кроют чистым золотом», и «Джон Ланкастер в одиночку, преимущественно ночью»... И все метропольцы тут расшевелились и загудели.

Сейчас вот, в заокеанском отдалении, смотрю на снимки этого вечера. Толкучка талантов, и среди них он - хриплый проспиртованный Орфей нашей невеселой метрополии.

\section{Публикачия и примечания Виктора ЕСИПОВА и Андрея КУЛИКА}

${ }^{1}$ В. Аксенов звонил Б. Ахмадулиной. Она вспоминала потом, что Аксенов позвонил ей из Парижа и, услышав, что ночью умер Владимир Высоцкий, закричал в трубку: «Не верю! Не может быть!» См.: [Meccepep 2012: 252].

2 Теплоход «Грузия» курсировал от Батуми до Одессы и обратно.

${ }^{3}$ Капитан Анатолий Гарагуля дружил со многими писателями, собиравшимися в ресторане теплохода во время стоянки в Ялте, где был писательский Дом творчества.

${ }^{4} \mathrm{~B}$ «Песне о сентиментальном боксере» В. Высоцкого - Борис, но в «Ожоге» у Аксенова, где он цитирует эту песню, - Иван.

${ }^{5}$ Михаил Михайлович Шемякин (род. 1943) - американский и российский художник, в эмиграции с 1971 года.

${ }^{6}$ Стихотворение А. Вознесенского «Реквием оптимистический 1970-го года» (1971).

7 Этот факт отображен в кинофильме П. Буслова «Высоцкий. Спасибо, что живой» (2011).

\section{Литература}

Meсcерер Б. В бесконечном объятии // Василий Аксеноводинокий бегун на длинные дистанции / Сост., предисл. В. Есипова. М.: Астрель, 2012. С. 248-253. 


\section{References}

Messerer, B. (2012). In the endless embrace. In: V. Essipov, ed., Vasily Aksyonov - the lonely long-distance runner. Moscow: Astrel, pp. 248-253. (In Russ.)

\section{Vasily Aksyonov on Vladimir Vysotsky}

DOI: $10.31425 / 0042-8795-2018-4-191-198$

\section{Viktor M. Essipov}

literary historian

A. M. Gorky Institute of World Literature of the Russian Academy of Sciences

(25a Povarskaya St., Moscow, 121069, Russia;

email: wogeman@mail.ru)

\section{Andrey P. Kulik}

literary historian, independent researcher

(21-3 Soboleva St., Yekaterinburg, 620036, Russia;

email: nihil1@yandex.ru)

Abstract: The annotated transcript of V. Aksyonov's radio program about V. Vysotsky recorded at the Radio Svoboda studios in July 1983. Aksyonov confessed that, although he had gotten used to all sorts of things during his life in emigration, he still struggled to accept the fact that 'Volodya was no longer with us'. V. Aksyonov reminisces about his encounters with Vysotsky, sharing various stories from his life and the origins of the Metropol almanac.

Keywords: V. Aksyonov, V. Vysotsky, Metropol almanac.

The article was received on 1 Dec. 2017. 